\title{
THE JĘDRÓW HISTORIC HYDROTECHNICAL SYSTEM- A GEOARCHAEOLOGICAL AND RESTORATION STUDIES (HOLY CROSS MOUNTAINS, POLAND)
}

DOI: https://doi.org/10.18509/AGB.2021.17

UDC: $626.816: 902.2(438)$

\author{
Tomasz Kalicki ${ }^{1}$, Paweł Przepióra ${ }^{1}$, Sławomir Chwałek $^{2}$, \\ Michal Aksamit ${ }^{2}$, Paulina Grzeszczyk ${ }^{2}$, Geoffrey Houbrechts ${ }^{3}$
}

\author{
${ }^{I}$ Institute of Geography and Environmetnal Sciences, Jan Kochanowski University in Kielce, Poland \\ ${ }^{2}$ Student Science Club of Geomorphologists „Złoty Bażant”, Jan Kochanowski University in Kielce, Poland \\ ${ }^{3}$ University of Liège, Unit of Physical Geography and the Quaternary Period (UGPQ), Belgium
}

corresponding author: m.aksamit1989@gmail.com

\begin{abstract}
The purpose of recognizing the hydrotechnical infrastructure and metallurgical activity traces state is to provide restoration protection to Jędrów water mill building and its surrounding area. In the past, this area was used economically and was a part of the Old Polish Industrial District (central Poland). Jędrów is an example of disappearance of industry development, anyway the hydrotechnical infrastructure is still preserved here and visible even on the digital elevation model (DEM). Infrastructure elements such as embankments, channels and former pond basin are clearly visible here. The obtained echograms from GPR survey show geological changes that may reflect sediments filling the currently landed industrial pond. Well visible anomalies are most likely related to the slag deposits. Preliminary results from macro- and micro-slag analysis were obtained, which revealed the presence in overbank sediments of a large number of microscopic iron spheres (balls) indicating the accumulation of metallurgical activity material.
\end{abstract}

Keywords water mill, overbank sediments, lacustrine sediments, historical metallurgy, slag deposits.

\section{INTRODUCTION}

Jędrów is located in the central part of the Kamionka catchment area. It is a $17 \mathrm{~km}$ length meandering, mountain river (Holy Cross Mountains, central Poland) (Fig. 1). The first traces of metallurgy developing in this area come from prehistoric times [1], [2]. Its intensive development in the Middle Ages until the end of the 19th c. left a very clear mark on the landscape in Old Polish Industrial District area [3]. When the mining and metallurgy in this region collapse, in some places mining and processing of iron ore was still operate even until the first half of the 20th c. Water mills were built in the direct vicinity of the forges or in their foundations. The water mills activitie also had a very significant impact on the transformation of many river systems i.a. [4], [5], [6], [7], [8], [9], [10]. Traces of these changes related to the operation of the forge and then the water mill are very clear in the Kamionka flodplain near Jędrów. 


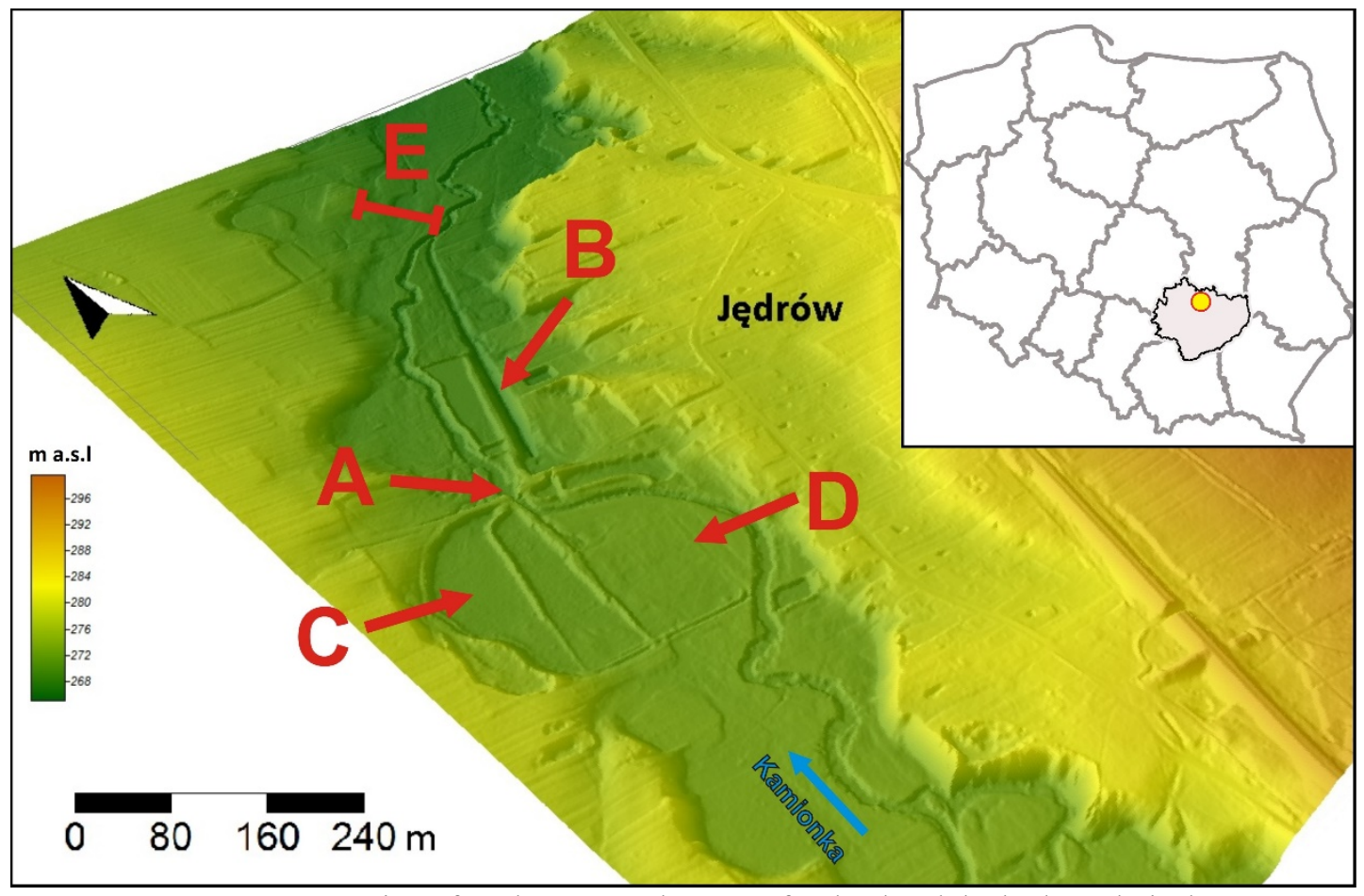

Figure 1. Location of study area on the map of Poland and the hydrotechnical infrastructure main elements near Jędrów water mill

A - water mill building and weir on the river, B - mill race,

$\mathrm{C}$ - former fish reservoir with preserved dykes, D - former industrial reservoir area,

E - cross section location; DEM ed. by M. Frączek based on date from CODGiK

(MGGP Aero, Nr GI-FOTO.703.44.2014).

\section{AIM OF THE STUDY AND METHODS}

The aim of study is to recognize the traces preserved in the Kamionka floodplain forms and sediments created during the Jędrów water mill and former forge development. For this purpose, boreholes (Eijkelkamp manual drill) and geophysical analysis (MALA Georadar ProEx with a $500 \mathrm{Mhz}$ antenna) were made. The obtained samples were grain size analyzed (set of 2800-63 $\mu \mathrm{m}$ test sieves and Retsh and Morek-Multiserw laboratory shakers) and performed dating using the OSL (natural radionuclide analyzer MAZAR - 01 and Manual Reader-Analyser TL/OSL RA'04 manufactured by the MIKROLAB company) and

\section{RESULTS}

Kamionka river has been intensively developed by man since the Middle Ages as a power source for nearby metallurgical facilities and grain mills operating in the Old Polish Industrial District area. The mining of Iron ore in the surrounding hills led to build about 7 forges in the Kamionka catchment. One of them was located at Jędrów, near the current water mill [1], [11]. First time this forge was recorded in 1530, while information about the mill itself appears in 1859. In 1863, the wooden structure was burned, and the present red brick building has been operating since 1911, which is also by archival materials confirmed [11], [12]. the radiocarbon method (made in Laboratorium Datowań Bezwzględnych at Skała). Also the separation of macro- and microscopic slag fragments from overbank and lacustrine sediments (600-212 $\mu \mathrm{m})$, and ferromagnetic residues from metallurgical activity in the form of microscopic iron balls $(212-63 \mu \mathrm{m})$ was done. The method using magnes to separate ferromagnetic elements from sediments was never before used in Holy Cross Mountain region. The obtained data were verified using many historical documents and archival maps, which presented the location of former industrial centres in study area.

The increase of the metallurgical centers in the central part of the catchment led to many relief transformations, including of some sections of the riverbed changes (artificial channels, millraces and various sizes ponds). Some of the water reservoirs have been rebuilt, sometimes even several times but mostly smaller were drained. Some of old water mills infrastructure remained after many years. The water mill at Jędrów together with the surrounding area perfectly fits into the situation described above.

In places where the forge and water mill was operate, dams and weirs were built on the river. The 
small industrial ponds guaranteed power to water wheel driven facilities. At the turn of the 19th and 20th c., the metallurgical industry based on forges development collapsed. This led to the abandonment and destruction of hydrotechnical infrastructure in the river. Until the half of 20th c, only a few water mills operated in Kamionka. After their fall, the dams on the river were destroyed, so the ponds were drained. In their place the basin was filled with sediments and become part of floodplain.

This situation also took place, i.a. at Jędrów. The current renovation works of the water mill and reconstruction of the dam are leading to further changes of the Kamionka riverbed on this section [11].

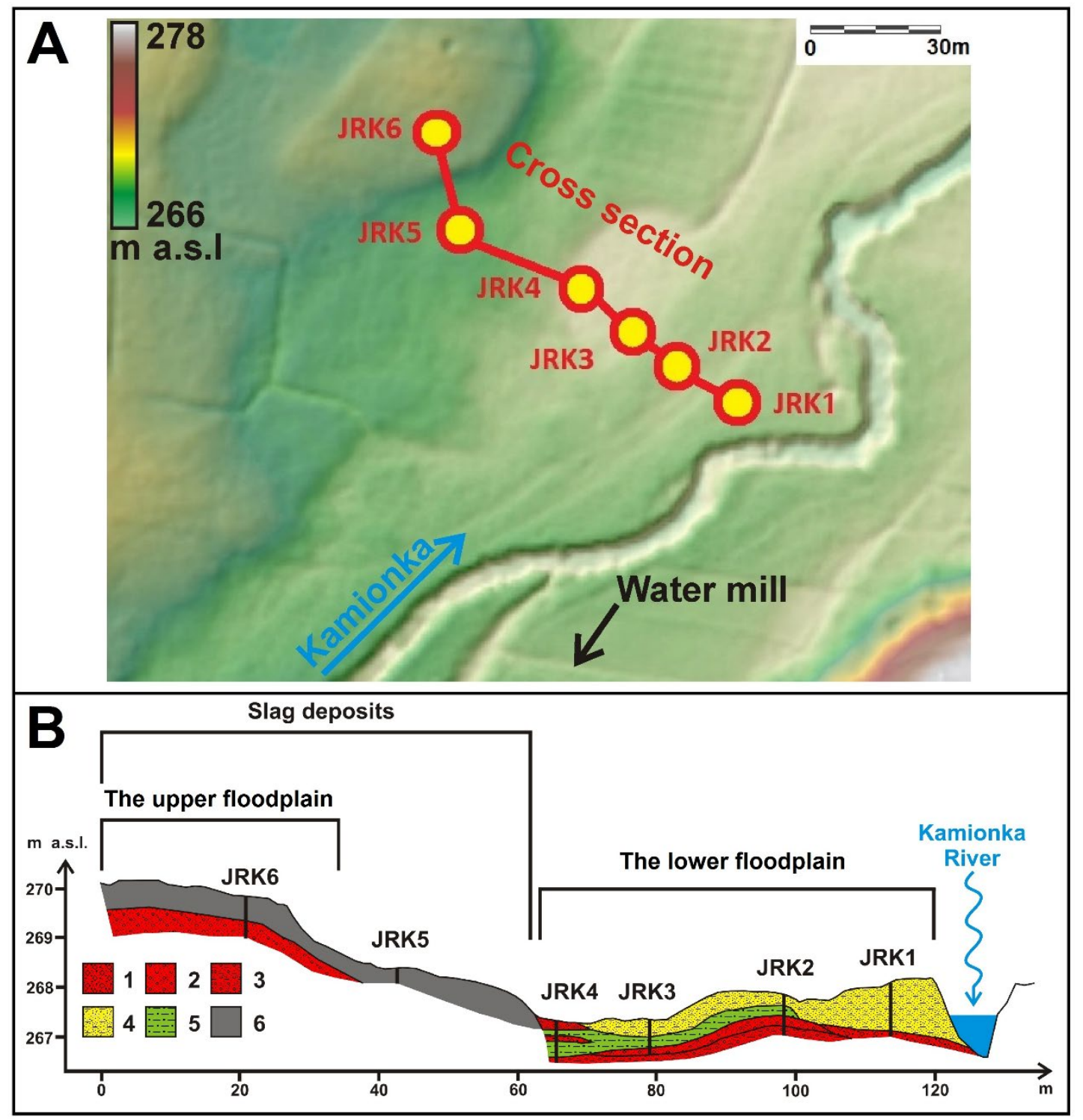

Figure 2. The location of the boreholes (A)[13] and cross section of the Kamionka floodplain downstream of the Jędrów water mill

1 - sands with gravels, 2 - sands with single gravels, 3 - silty sands with gravels, 4 - silty sands, 5 - sandy silts, 6 - embankment.

The previous studies in this area discovered traces of Jędrów industrial past. They were found in the alluvial floodplain north of the water mill (about $450 \mathrm{~m}$ downstream), and mainly are industrial residues in the floodplain deposits like contemporary ceramic pieces, slags or distinct layers with charcoal inserts dated by OSL method (0.44 $\pm 0.06 \mathrm{ka}$; UJK-OSL-68) and $14 \mathrm{C}$ (40 \pm 80 BP or 1799-1943 cal AD; MKL-3250) [10], [12]. Boreholes were made near the millrace estuary to the Kamionka riverbed. From the samples the material for macro- and micro-slag analysis was obtained (Fig. 2). Preliminary results of these analyzes showed the accumulation of large, several $\mathrm{cm}$ of slag in sandy sediments (JRK5 profile) near the edge of the upper floodplain (slag pile?). In boreholes located closer to the riverbed, the smaller fragments of slag with a size from several $\mathrm{cm}$ to $212 \mu \mathrm{m}$ (JRK2 profile) in overbank sediments were also found. The presence 
of characteristic, microscopic iron balls (spheres) with 212-63 $\mu \mathrm{m}$ size (JRK2 and JRK1 profiles) was detected in the overbank sediments. On the floodplain located south-west of the water mill, traces of former water reservoirs are still visible. This area is surrounded by fragments of earth embankments (most likely the remains of breeding ponds, as well as one in north of the water mill)(Fig. 1). These ponds are currently poorly visible in the field and their location is only possible due to DEM maps or boreholes, in which sometimes thinner layers of post-production waste (slag) are deposited (Fig. 3) [10], [11].

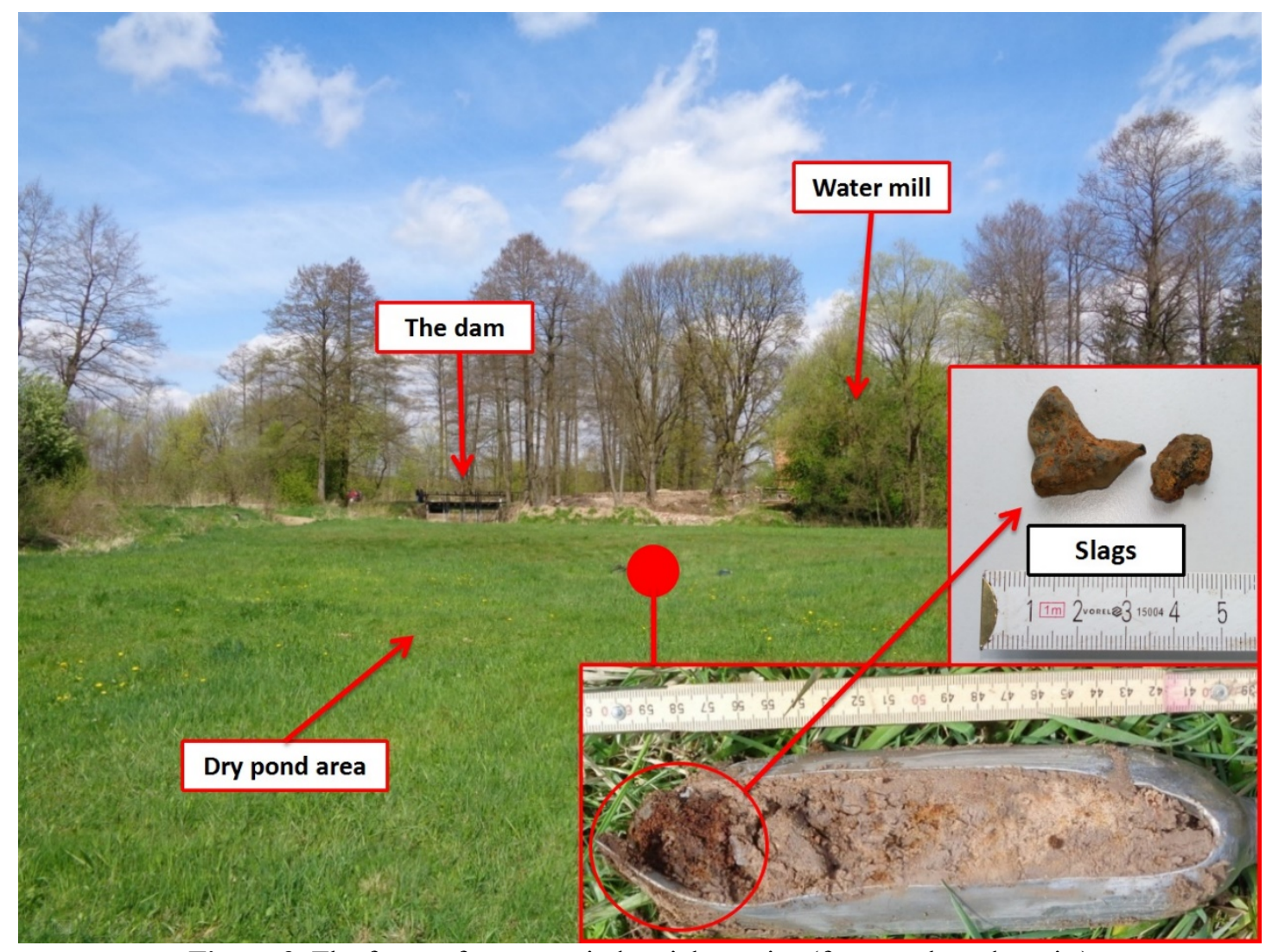

Figure 3. The former forge post-industrial remains (few $\mathrm{cm}$ slags deposits) discovered in former pond lacustrine sediments (photo from 2015).

Using a non-invasive geophysical GPR method the former pond area was analyzed. A four echograms were made, three transverse and one along the pond basin (Fig. 3). They allowed to locate, among others the borders of the former water reservoir and changes in sediments filling its bottom. The first three echograms were led across the former pond basin towards EW. The PJ1 cross-section (Fig. 3) is located in the southern part of the studied area and is about $110 \mathrm{~m}$ long. The maximum signal range reaches about $4 \mathrm{~m}$ depth into the ground, while most of the anomalies are visible up to about $2 \mathrm{~m}$ depth. The one string of anomalies is visible from about 20 $\mathrm{m}$ (distance) to the end of the profile. Those anomalies reaching up to $3 \mathrm{~m}$ depth, while at $35 \mathrm{~m}$ (distance) an anomaly reaches up to $4 \mathrm{~m}$ depth. The PJ3 echogram (Fig. 3) is located in the central part of the pond area and it have $110 \mathrm{~m}$. The maximum signal range also reaches about $4 \mathrm{~m}$ depth.
Anomalies in this echogram are visible up to a maximum of $3 \mathrm{~m}$ depth and their largest number is in the eastern section. Another PJ4 echogram (Fig. 3) was made in the northern part of the former reservoir. This cross-section is shorter due to the narrowing of the pond basin and is about $80 \mathrm{~m}$. The maximum signal range is about $3.5 \mathrm{~m}$ depth. At about $1 \mathrm{~m}$ depth an anomaly for all along of the cross-section is visible. The PJ5 (Fig. 3) is a longitudinal cross-section of NS arrangement. It is perpendicular to the rest of the echograms and is about $160 \mathrm{~m}$ long. The maximum signal range reaches about $3 \mathrm{~m}$ depth. The visible anomaly is extends from about 5 to $22 \mathrm{~m}$ at a maximum depth of $2.8 \mathrm{~m}$, and then shallows to about $0.5 \mathrm{~m}$ depth at $32 \mathrm{~m}$ (distance). Next anomalies appear again in the $2.8 \mathrm{~m}$ depth, which stretch from $60 \mathrm{~m}$ to the end of the cross-section. 


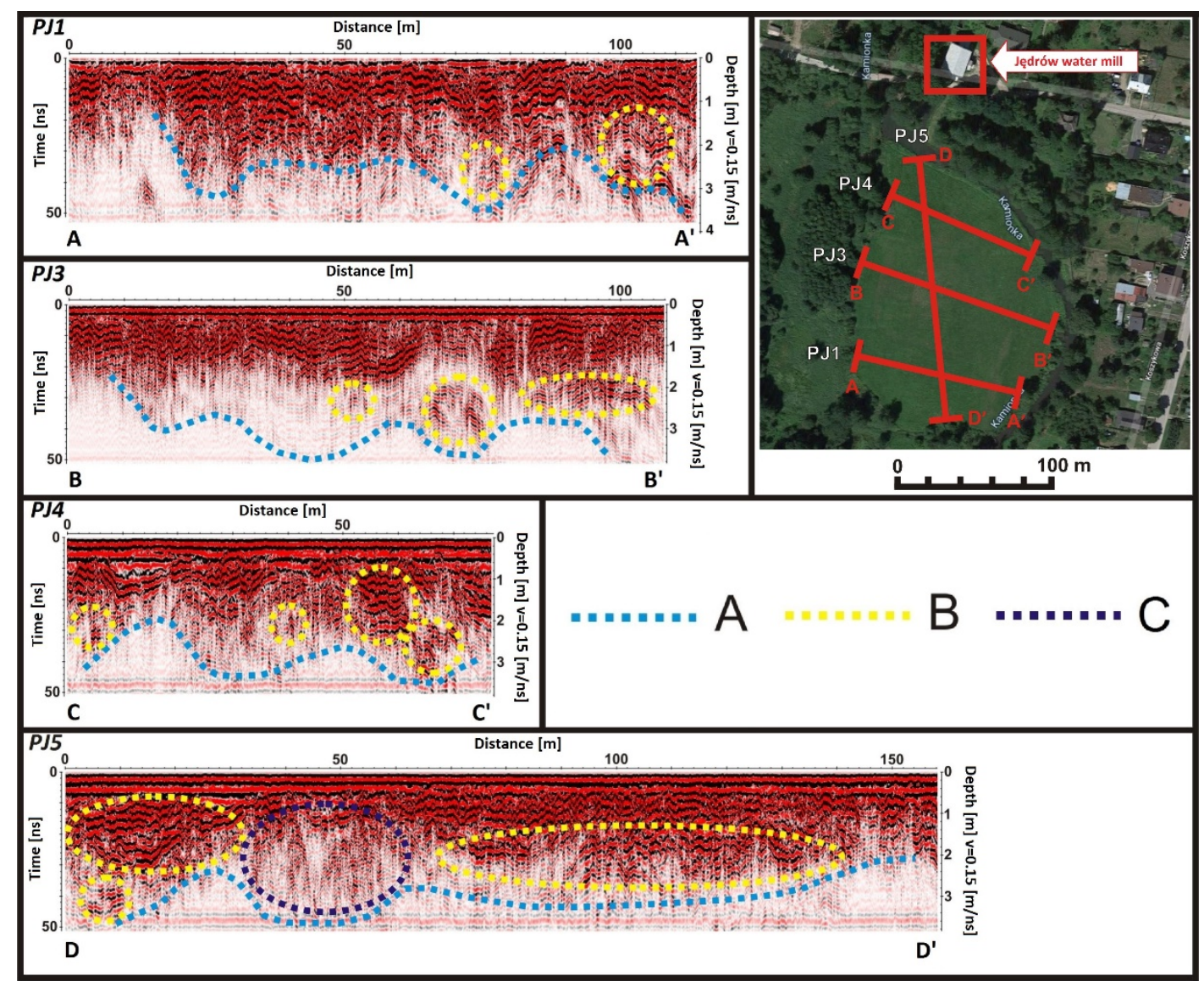

Figure 4. The echograms and theirs location in the bottom of a Jędrów former pond area on an orthophotomap background [13]

A - estimated water reservoir bottom filed with sediments,

B - a strong signal coming probably from the slag deposits in the sediments, $\mathrm{C}-$ the shallow area, probably dike or embankment.

\section{DISCUSSION}

The various elements of hydrotechnical infrastructure in the study area have survived. Some of them with the water mill building have been renovated (Fig. 1) and working again, e.g. weir, which results in raising the water level in the river upstream from the water mill. In this part of floodplain area the pond was located near the former forge.

It is evidenced by post-industrial residues (slags, charcoals) in lacustrine and overbank sediments. Slags in sediments are a remnant of metallurgical activity, which is confirmed by research from other regions of Europe, i.a. Ardennes region [14], [15]. After the collapse of industry, the reservoir at Jędrów was used by a water mill. Many similar ponds in Kamionka formed an anthropogenic small-scale water retention system, which additionally alleviated possible floods on the river [16]. The archival materials and old maps show ponds (1801-1859) appearing upstream and downstream from the water mill. Later (1873-1927) those ponds disappear and in their place appear smaller reservoirs (1938). The functioning of these smaller ponds is confirmed by, i.a. GPR analyzes
(Fig. 4), which showed the occurrence of two large anomalies (most likely former pond basin with lacustrine sediments) separated by a clear shallow area (embankment?), visible in the PJ5 crosssection.

Many smaller but well visible anomalies can be conected with the slag deposits in the lacustrine sediments. With a compact plant cover, the DEM was very helpful in locating rest of the remains of the hydrotechnical infrastructure (Fig. 1).

Slags and microscopic iron balls (spheres) discovered in overbank sediments (Fig. 5) providers the functioning of metallurgical facility in this area [14], [17], [18]. Bigger slag fragments in sediments are deposited at various depths. This indicates slags redeposition by regulated river in the last centuries. They also form a clear pile under the upper floodplain edge (Fig. 2), which may confirm the functioning of the forge downstream of the Jędrów water mill.

Smaller, iron balls, often empty inside, formed at high temperatures during smelting of iron ore in furnaces. They were transported by aeolian, and then redeposited by fluvial processes, covered by 
overbank sediments. Origin of post-industrial layers formed in sediments, i.a. charcoals confirms by OSL and $14 \mathrm{C}$ dating $(0.44 \pm 0.06 \mathrm{ka}$; UJK-OSL$68)$ and $14 \mathrm{C}(40 \pm 80 \mathrm{BP}$ or $1799-1943 \mathrm{cal} \mathrm{AD}$;
MKL-3250) [10], [12]. This dates matches the period of activities of the 19th c. forge at Jędrów [12], as well as increased activity of charcoal hearths in Old Polish Industrial District area [19].

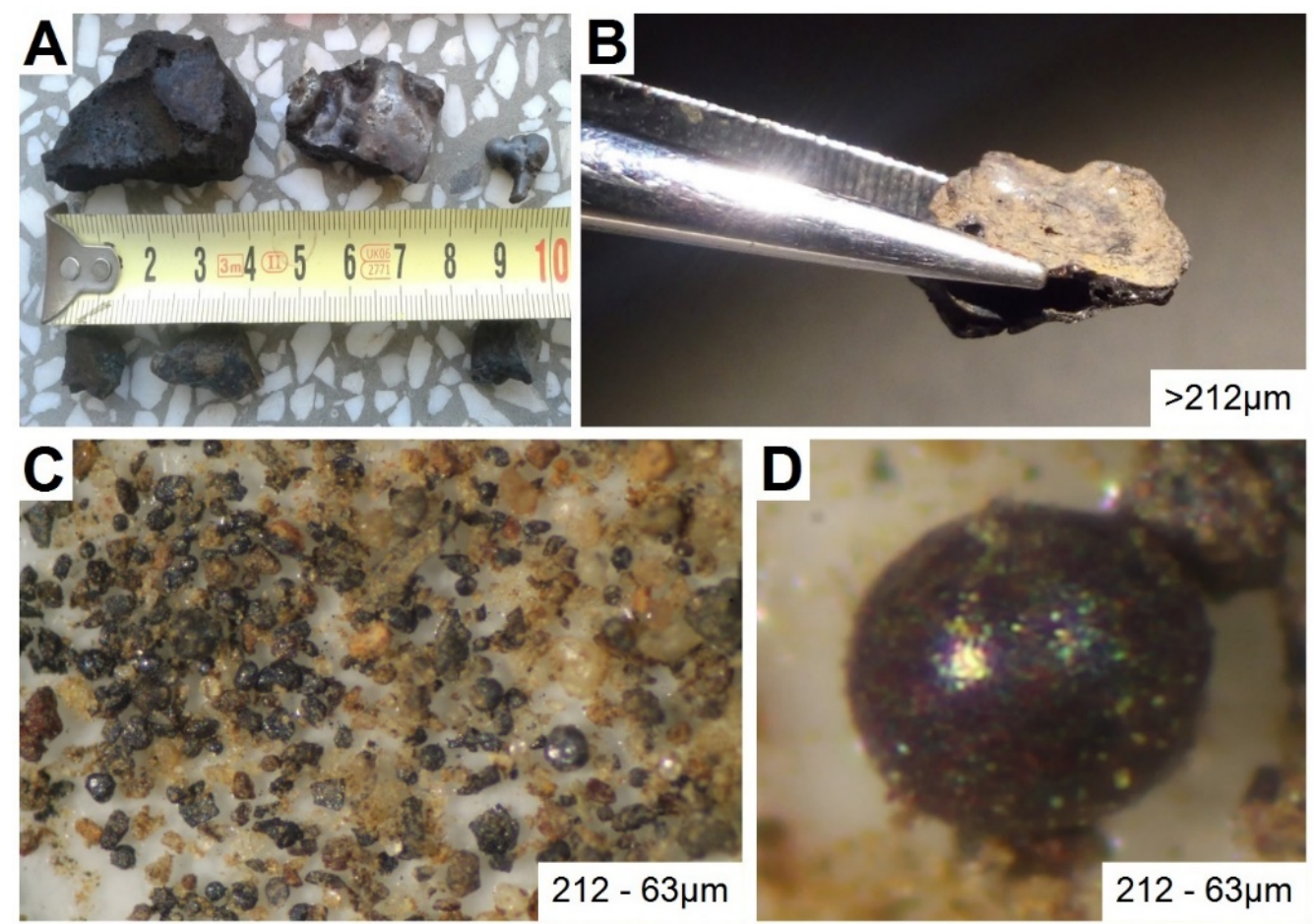

Figure 5. The former forge post-industrial remains in overbank sediments about $450 \mathrm{~m}$ downstream of the Jędrów reservoir

A - few cm slags in JRK5 borehole, B - macroscopic slag fragments in JRK2 borehole, $\mathrm{C}-$ microscopic iron balls of anthropogenic origin in JRK1 borehole, D - zoom of the iron ball.

\section{CONCLUSIONS}

The Jędrów water mill with remaining infrastructure is one of the few of this type facilities in Holy Cross Mountains region that has in such good condition preserved. Like many industrial objects belonging to the Old Polish Industrial District, traces of metallurgical activity are very well visible here. They can be found in relief (slag mound, hydroelectric infrastructure of the forge and water mill) and in sediments (macro- and microslags or microscopic iron balls). The building itself has now been rebuild by new owners and work to restore the former splendor of this facility is still in progress. The current condition of the water mill has contributed to enter this object in the register of monuments and to restore it. This is extremely important due to the historic water mill protection, but also to the heritage preservation of the metallurgical industry of the Old Polish Industrial District, which also left clear marks in the surrounding landscape [20].

\section{ACKNOWLEDGMENTS}

Many thanks to Marcin Frączek and Ellynn Bertemes, for help in the field and laboratory work. Special thanks go to Świętokrzyskie Voivodship Monuments Conservator, Mrs. Anna Żak, on which order the geoarchaeological expertise was commissioned. We would also like to thank Anna Mazur-Orłowska and Piotr Orłowski, the current owners of the water mill in Jędrów, they made it possible to carry out research in its immediate surroundings.

\section{REFERENCES}

[1] Bielenin K. Starożytne górnictwo i hutnictwo żelaza w Górach Świętokrzyskich, Wydanie drugie, poszerzone i poprawione, Kieleckie Towarzystwo Naukowe, 1993.

[2] Orzechowski Sz. Zaplecze osadnicze i podstawy surowcowe starożytnego hutnictwa świętokrzyskiego, Kieleckie Towarzystwo Naukowe, Kielce, 2007.

[3] Zieliński J. Staropolskie Zagłębie Przemysłowe. Kieleckie Towarzystwo Naukowe, Ossolineum, pp. 339, 1965. 
[4] Kaniecki A. Młyny wodne w dawnym Poznaniu i ich wpływ na przeobrażenie stosunków wodnych. Act Univ. N. Copernici, Geogr. 29, UMK, Toruń, 1999.

[5] Podgórski Z. Wpływ budowy i funkcjonowania młynów wodnych na rzeźbę terenu i wody powierzchniowe Pojezierza Chełmińskiego i przyległych części dolin Wisły i Drwęcy. UMK, Toruń, 203, 2004.

[6] Krupa J. Natural and anthropogenic channel pattern changes in the mid-mountain valley during the Late Glacial and Holocene, Polish Uplands. Quaternary International, 370, pp. 55-65, 2015.

[7] Kusztal P., Kalicki T., Chrabąszcz M., Frączek M., Kłusakiewicz E., Przepióra P., \& Zaborska D. Nowożytne zakłady hutnicze i młyny a rozwinięcie koryta Czarnej Koneckiej powyżej zalewu w Sielpi (region świętokrzyski). Materiały Konferencyjne Interdyscyplinarnego Seminarium Naukowego „Młyny wodne w dorzeczu dolnej Wisły od początku XVIII do początku XXI wieku”, D. Brykała, M. Prarat, P. Lamparski (eds.), UMK, Toruń, pp. 46, 2017.

[8] Chrabąszcz M., Kalicki T., Przepióra P. \& Frączek M. Zmiany koryta dolnej i środkowej Wiernej Rzeki od XVIII wieku. Acta Universitatis Lodziensis, Folia Geographica Physica, 16, pp. 5-13, 2017.

[9] Mięsiak-Wójcik M. Analysis of water retention changes in selected lake-wetland catchments of West Polesie based on historical documents. Limnological Review, 18, 2, pp. 59-75, 2018.

[10] Kalicki T., Frączek M., Przepióra P., Kusztal P., Kłusakiewicz E. \& Malęga E. Late Quaternary geomorphology and geoarchaelogy in the rivers of the Holy Cross Mountains region, Central Europe. Quaternary Research, Vol. 91, (2), pp. 584-599, 2019.

[11] Przepióra P. Naturalne i historyczne zmiany zlewni Kamionki (Płaskowyż Suchedniowski), PhD thesis, Jan Kochanowski University in Kielce, 2017.

[12] Piasta S. Leksykon Suchedniowa, Towarzystwo Przyjaciół Suchedniowa, Kielce, 2012.

[13] geoportal.gov.pl.

[14] Houbrechts G. \& Weber J.P. La sidérurgie proto-industrielle dans le bassin de la Lienne, De la Meuse à l'Ardenne, Entre Ardenne et Meuse ASBL, 39, pp. 34-63, 2007.

[15] Notebaert B., Houbrechts G., Verstraeten G., Broothaerts N, Haeckx J., Reynders M., Govers G., Petit F. \& Poesen J. Fluvial architecture of Belgian river systems in contrasting environments: Implications for reconstructing the sedimentation history. Netherlands Journal of Geosciences - Geologie en Mijnbouw 90 (1), pp. 31-50, 2011.

[16] Kalicki T., Przepióra P., Aksamit M., Frączek M., Kłusakiewicz E. \& Grzeszczyk P. Forming and disappearance of small retention system in the postindustrial area - case study from the central section of the Kamionka river valley (Central Poland) since the 18th century. Acta Geobalcanica, 5-1, pp. 29-34, 2019.

[17] Richardeau C. Distribution des sphèrules magnétiques provenant de la sidérurgie liégeoise, dans B. S. G. Lg, 13 pp. 155-165, 1977.

[18] Houbrechts G. \& Petit F. Utilisation des microscories métallurgiques comme traceur de la sédimentation dans les plaines alluviales des rivières ardennaises, Numéro spécial des Presses Universitaires Blaise Pascal, dans la collection Nature et sociétés,, pp. 95-98, 2006.

[19] Rutkiewicz, P., Malik, I., Wistuba, M. \& Osika, A. High concentrations of charcoal hearth remains as legacy of historical ferrous metallurgy in southern Poland. Quaternary International, 512, pp. 133-143, 2019.

[20] Kalicki T. \& Przepióra P., (cooperation with Chwałkiem S. i Frączkiem M.). Lokalizacja oraz zasięg historycznego układu hydrotechnicznego z młynem wodnym w Jędrowie (obecnie: ul. Koszykowa 18b w Suchedniowie) ekspertyza geoarcheologiczna. Zlecone przez Wojewódzki Konserwator Zabytków w Kielcach, 2019. 